\title{
FOREST RESEARCH IN BRITAIN
}

$I^{\mathrm{T}}$ is now about ten years since the Forestry Commission Research Station at Alice Holt was opened, and the Commission's Research Branch, which might previously have been described with only slight exaggeration as 'a one-man show', was enlarged so as to enable it to deal more adequately with the diversity of problems which are encountered in the practice of forestry. The annual Report on Forest Research in Britain*, which prior to 1950 had been a modest, privately circulated document, has now become a publication which is essential to anyone who wishes to remain informed on modern developments of forestry technique. It reports not only the progress of work by the Commission's own research branch, but also of work carried out with the support of the Commission in university departments, and although the detailed results of most of this latter research will usually be published elsewhere, the report of the Research Branch provides a compact and often early summary.

The present phase of the Commission's research is essentially one of consolidation and continuation of work which was started after the expansion of 1947 ; many new developments cannot be expected. For the first time, however, the soil chemist now attached to Alice Holt reports on his work, which has been largely of a preliminary and routine nature, including the analysis of plant tissues in addition to that of soils. Economics was the principal branch of forest research which was unrepresented during 1955-56; this doficiency has now been made good by the appointment of a district officer for economics research.

The practice of forestry draws upon a wider range of techniques than do most comparable arts, and accordingly the investigations carried out by or for the Commission range over subjects as diverse as the performance of planting machines and the biology of

* Report on Forest Research for the year ended March 1956. Forestry Commission publication. Pr. vi ît-172. (London: H.M. Stationery Office, 1957.) 6s. net. oribatoid mites. Much of the work is of a simple kind and is designed to decide practical details in technique. It is sufficient to note here with satisfaction that these details are being made the subject of thorough investigation and that many new procedures, some of them unconventional, are being explored; the impression is given that the Commission's research staff is fully alive to the need for constantly reviewing forestry technique as new methods become practicable and as economic conditions change.

It is appropriate here to direct attention to some of the research which has a wider scientific interest. Dr. Rishbeth's work on the fungus Fomes annosus, which has already yielded such important results, has been resumed, and the Commission's research branch is energetically studying its practical implications. The fungi Meria laricis and Keithia thujina are becoming the subjects of intensive study at the Universities of Southampton and Nottingham respectively. Dr. Manners's work at last seems to be deciding the relative importance of frost and of the fungus Trichoscyphella in causing larch canker.

Entomological work has been dominated by the pine looper moth, Bupalus pinarius, but the larch sawflies and the pine weevil, Hylobius abietis, have also received attention, and the discovery at many stations in Scotland is reported of the bark beetle Ips cembrae, a potentially serious pest of larch. The distribution of red and grey squirrels is noted.

The application to the soil of formalin and alternative sterilizing agents is still being studied; it is now reported that the resulting stimulation of tree seedlings cannot be ascribed to the destruction of fungi parasitic on the roots. Other investigations concern the use of fertilizers, a copper deficiency on heathland soils, and the action of mycorrhizæ. Dr. Murphy's report on the biology of oribatoid mites which live in forest litter is also noteworthy. E. W. Jones

\section{THE GOLGI CONTROVERSY}

\author{
By PRoF. VISHWA NATH \\ Department of Zoology, Panjab University, Hoshiarpur, India
}

\begin{abstract}
$\mathrm{U}$ NDER the above title, J. R. Baker' has very ably summed up the evidence in favour of his now well-known view that we should concentrate on an objective study of the cytoplasmic inclusions and discard once for all the use of the terms 'Golgi apparatus', 'Golgi bodies', 'Golgi substance', etc. He has marshalled his evidence under three headings : (a) evidence from morphology; (b) evidence from histochemistry; and $(c)$ evidence from ontogeny.

The purpose of this communication is to scrutinize the evidence furnished by the school of cytology at Oxford in the light of our own work done in the Department of Zoology, Panjab University, Hoshiarpur, and see if we can arrive at some definite conclusions.
\end{abstract}

(a) Evidence from morphology. Baker' has given three examples of the many different kinds of cells that he and his colleagues have examined.

(i) Neurones of the thoracic ganglia of Locusta. Shafiq ${ }^{2}$, working on the neurones of Locusta, describes only two cytoplasmic inclusions, namely, $(a)$ homogeneous globules stainable in life by neutral red (lipochondria), and (b) filamentous and granular mitochondria, stainable by janus green. Shafiq ${ }^{2}$ used the osmium and silver 'Golgi techniques' on the lipochondria and observed that the lipochondria now reveal a black cortex and a pale medulla; and he interpreted these appearances as artefacts.

In our laboratory, Malhotra ${ }^{3}$ has worked on the neurones of Schistocerca and Lascotrephes, Anadenus 